\title{
Simple and Reliable Method for the Estimation of Albendazole in Antiparasitic Drug Formulations
}

\author{
Umesha K. Bhadraiah ${ }^{1 \mathbb{D}}$, Manasa Chandramouli ${ }^{2 \mathbb{D}}$, Vrushabendra Basavanna ${ }^{2 \mathbb{D}}$, Srikantamurthy \\ Ningaiah 2,*(i) \\ Department of Chemistry, Yuvaraja's College, University of Mysore, Mysore-570005, Karnataka, India \\ Department of Chemistry, Vidyavardhaka College of Engineering, Mysore-570002, Karnataka, India \\ * Correspondence: srijmn@vvce.ac.in, kbu68umesha@rediffmail.com;
}

Scopus Author ID 55786395000

Received: 1.10.2020; Revised: 22.10.2020; Accepted: 23.10.2020; Published: 25.10.2020

\begin{abstract}
From the literature survey, it is confirmed that there are only a few analytical methods for the determination of albendazole. The principle behind this investigation is to produce a simple, exact and quick method of titrimetry for the quantification of albendazole. Albendazole having an oral broadspectrum biological activity present in pharmaceutical drugs is determined using a conventional and reliable iodometric method using chloramine-T as an oxidant. The method involves the oxidation of sulfur by chloramine- $\mathrm{T}$ in glacial acetic acid, followed by the iodometric determination of the unreacted chloramine-T.
\end{abstract}

Keywords: albendazole (ABZ) drugs; chloramine-T (CAT); iodometry; oxidant.

(C) 2020 by the authors. This article is an open-access article distributed under the terms and conditions of the Creative Commons Attribution (CC BY) license (https://creativecommons.org/licenses/by/4.0/).

\section{Introduction}

Albendazole is related to mebendazole structurally [1]. It is an anthelminthic [2], chemically known as methyl-5-(propylthio)-2-benzimidazole carbamate. It is broadly categorized as antiparasitic pharmaceuticals [3]. The large scale of animal breeding is a result of the evolution of civilization [4]. Albendazole was probably recognized for treating the infections caused by a variety of worms [5]. Albendazole is targeted for a parasite named echinococcosis that causes abscess in the liver and lung [6]. Albendazole persists as a contaminant in the soil, thus possessing ecological importance [7]. A restricted barrier is posed for its usage due to its insolubility in water [8]. An antihelminthic in nature, albendazole is capable of causing a wide variety of diseases in the host. Albendazole first came upon in 1972 at Smith Kline animal health laboratories [9]. It has proved its efficiency against the liver flukes for cattle, goats, sheep, pigs, dogs, and cats, including humans [10]. It affects the host by binding to the parasite's tubulin and thus blocking the glucose absorption [11]. This action leads to disorders like thirst, vomiting, nausea, constipation, hair loss, dizziness, headache, and pruritus [12]. Albendazole is an alternative therapeutic agent for childhood giardiasis in taste [13]. Albendazole is used in feeds to control fasciolosis Magna infection in captive white-tailed deer [14]. The usual techniques that are resolute to the determination of albendazole and its metabolites are HPLC method [15], gas chromatography [16], capillary electrophoresis [17], UV spectrophotometry [18], thin layer chromatography [19], voltammetric method [20], and liquid chromatography [21]. 
Basavaiah and co-workers [22] applied the spectrophotometric and sensitive titrimetric method for the determination of ABZ in bulk drug and in tablets using sodium periodate and two dyes, namely, methyl orange and indigo-carmine, as reagent with a satisfactory result. The enantiomer of albendazole sulfoxide in human plasma and saliva was analyzed using capillary electrophoresis with column absorption and fluorescence detection [23]. Maria Esther C et al. reported the HPLC method for the determination of the two major albendazole metabolites in plasma, viz., albendazole sulfone and albendazole sulfoxide [24]. In the present work, a reliable and cost-effective procedure is being reported for the determination of albendazole in the pharmaceutical samples.

Albendazole is a white to yellowish crystalline powder. ABZ is oxidized to a sulfoxide (ABZSO), which is, in part, further oxidized to a sulfone (ABZSO2); ABZSO is the main metabolite in vivo. The formation of ABZSO is directly associated with two different microsomal enzymatic system cytochrome P-450 and flavin-containing monooxygenase (FMO). The effect of albendazole treatment included a significant reduction $(\mathrm{P}<0.005)$ in parasite egg count per gram and a decrease in serum albumin [25].

Earlier, Rai et al. successfully utilized CAT for the determination of the iodine value of oils and fats [26] and the determination of neutral amino acids [27]. In the last decade, CAT was used as an oxidant in the estimation of carbonyl compounds [28], percentage of the enol form in the "-keto carbonyl compounds [29] and ascorbic acid in bulk and tablets [30]. Recently a laboratory work reported iodometric estimation of gabapentin in tablets using oxidant CAT [31]. Thus we extended the CAT as an analytical reagent for the determination of albendazole in tablets. The method reported here is that ABZ is known to undergo oxidation by CAT producing both sulphilimines and sulphoxides as diastereomeric products [32], and the overall reaction requires $1 \mathrm{~mol}$ of CAT per $1 \mathrm{~mol}$ of ABZ.

\section{Materials and Methods}

Reagents used were all of the analytical reagent grades, and distilled water was used throughout the experiment. ABZ containing pharmaceutical drugs were purchased from local commercial sources and used in the range $100-500 \mathrm{mg}$, and $0.01 \mathrm{~mol}$ of CAT were prepared using distilled water. The following commercial drugs were analyzed with 0.01 mol CAT solution; Zentel, X-worm, Ivoral, Womiban, Bendex-400, and Zalben.

\subsection{Procedure.}

An accurately weighed (20-60 mg) ABZ containing commercial pharmaceutical drugs were dissolved in $(10 \mathrm{ml})$ of glacial acetic acid in $250 \mathrm{ml}$ Erlenmeyer flask, and $0.01 \mathrm{~mol} \mathrm{CAT}$ $(20 \mathrm{ml})$ of the solution was added. Then the reaction mixture was shaken well and kept aside at room temperature for about $30 \mathrm{~min}$, after which $2 \mathrm{~N}$ sulphuric acid (5 ml) and $10 \%$ aqueous potassium iodide $(5 \mathrm{ml})$ solution were added. The liberated iodine was titrated against standard sodium thiosulphate $(0.01 \mathrm{M})$ solution using starch as an indicator. In a similar way, a blank solution was conducted without adding ABZ containing pharmaceutical drugs. From the difference in the volume of standard sodium thiosulphate solutions consumed, the amount of ABZ ('W') present in the pharmaceutical drugs was calculated using the following equation:

$$
W=\frac{m \mathbf{x}\left(V_{2}-V_{1}\right) \times \mathbf{x}}{2000 \times n}
$$


Where $\mathrm{M}$ is the molarity of sodium thiosulphate; V1 and V2 is the volume of sodium thiosulphate consumed for experimental and blank titration; $\mathrm{m}$ is the molecular weight of the $\mathrm{ABZ}$ and $\mathrm{n}$ is the number of moles consumed.

\section{Results and Discussion}

The method describes the oxidation of ABZ to sulfoxide (ABZSO) by CAT yielding $\mathrm{N}$-(p-Tolylsulfonyl) sulfilimines. Sometimes it leads to the significant formation of the byproduct sulfoxides. In other cases, the reaction gives poor results, which is totally depended on the bulkiness of the substituents of sulfides. Both sulphilimines and sulphoxides being the major components, are evinced to be diastereomeric and is showed to have an opposite configuration with respect to sulfur. This mechanism is mediated through the chlorosulphonium sulphone amidated ion pair. The resulting sulphoxide is yielded through the chlorosulphonium ion through the reaction of the mentioned intermediate proceeding from sulphurate intermediate over a-a type ligand exchange. a-e type of displacement is involved in the formation of sulphilimines. The proposed reaction mechanism is as shown in scheme 1 . Available methods involve a series of steps for the estimation of ABZ. The proposed method is much simpler than the literature method. It is evident that $1 \mathrm{~mol}$ of $\mathrm{ABZ}$ consumes $1 \mathrm{~mol}$ of CAT for its oxidation. It is noteworthy to observe that in this method, the relative percentage errors with respect to the amount of ABZ were less than $2 \%$ and are given in Table 1 .

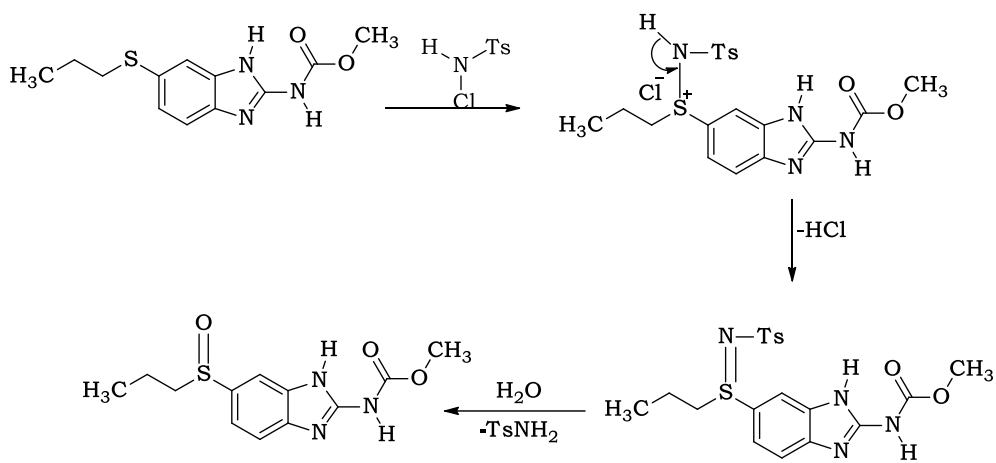

Scheme 1. A schematic representation of the mechanism of albendazole oxidizing to albendazole sulfoxide in the presence of chloramine-T.

Table 1. Amount of ABZ found in pharmaceutical drugs containing ABZ.

\begin{tabular}{|c|c|c|c|c|c|c|c|c|}
\hline $\begin{array}{l}\text { Name } \\
\text { of } \\
\text { drugs }\end{array}$ & $\begin{array}{l}\text { Trai } \\
1 \\
\text { No. }\end{array}$ & $\begin{array}{l}\text { Amount } \\
\text { taken } \\
(\mathbf{m g})\end{array}$ & $\begin{array}{l}\text { Amount found } \\
(\mathrm{mg})\end{array}$ & $\begin{array}{l}\text { Relative } \\
\text { error* } \\
(\%)\end{array}$ & $\begin{array}{l}\text { Name } \\
\text { of the drugs }\end{array}$ & $\begin{array}{l}\text { Amount taken } \\
(\mathrm{mg})\end{array}$ & $\begin{array}{l}\text { Amount found } \\
(\mathrm{mg})\end{array}$ & $\begin{array}{l}\text { Relative } \\
\text { error* }(\%)\end{array}$ \\
\hline 1 & 2 & 3 & 4 & 5 & 6 & 7 & 8 & 9 \\
\hline ZENTAL & $\begin{array}{l}1 \\
2 \\
3 \\
4 \\
5\end{array}$ & $\begin{array}{l}23.90 \\
28.88 \\
51.15 \\
33.48 \\
44.65\end{array}$ & $\begin{array}{l}22.90 \\
28.68 \\
50.90 \\
33.30 \\
44.46\end{array}$ & $\begin{array}{l}0.73 \\
0.69 \\
0.47 \\
0.53 \\
0.42\end{array}$ & WOMIBAN & $\begin{array}{l}32.00 \\
50.10 \\
68.00 \\
36.50 \\
27.50\end{array}$ & $\begin{array}{l}31.80 \\
49.57 \\
67.50 \\
36.30 \\
27.27\end{array}$ & $\begin{array}{l}0.62 \\
0.60 \\
0.73 \\
0.54 \\
0.83\end{array}$ \\
\hline X-WORM & $\begin{array}{l}1 \\
2 \\
3 \\
4 \\
5 \\
\end{array}$ & $\begin{array}{l}32.20 \\
39.30 \\
27.50 \\
35.40 \\
40.45 \\
\end{array}$ & $\begin{array}{l}32.00 \\
39.08 \\
27.20 \\
35.22 \\
40.14\end{array}$ & $\begin{array}{l}0.49 \\
0.53 \\
0.83 \\
0.76 \\
0.76 \\
\end{array}$ & $\begin{array}{l}\text { BENDEX- } \\
400\end{array}$ & $\begin{array}{l}53.79 \\
40.45 \\
45.31 \\
26.70 \\
52.20 \\
\end{array}$ & $\begin{array}{l}53.50 \\
40.14 \\
45.13 \\
26.52 \\
51.78 \\
\end{array}$ & $\begin{array}{l}0.53 \\
0.76 \\
0.39 \\
0.67 \\
0.80 \\
\end{array}$ \\
\hline IVORAL & $\begin{array}{l}1 \\
2 \\
3 \\
4 \\
5\end{array}$ & $\begin{array}{l}26.00 \\
30.00 \\
45.00 \\
55.10 \\
46.70\end{array}$ & $\begin{array}{l}25.98 \\
29.82 \\
44.80 \\
54.86 \\
46.25\end{array}$ & $\begin{array}{l}0.84 \\
0.66 \\
0.44 \\
0.36 \\
0.96\end{array}$ & ZALBEN & $\begin{array}{l}33.48 \\
26.00 \\
68.00 \\
39.80 \\
35.29\end{array}$ & $\begin{array}{l}33.30 \\
25.98 \\
67.50 \\
39.48 \\
35.05\end{array}$ & $\begin{array}{l}0.53 \\
0.83 \\
0.73 \\
0.80 \\
0.68\end{array}$ \\
\hline
\end{tabular}




\section{Conclusions}

Results from the present work reveal titrimetric methods are widely used and the simplest method for chemical analysis. Even though it is a classical method, it still plays a key role in the field of chemistry. We conclude that the proposed method in the present work provides a new simple selective, rapid, economical, accurate, and more precise method for the Iodometric determination of ABZ in pharmaceutical drugs by using CAT as an oxidant.

\section{Funding}

This research received no external funding.

\section{Acknowledgments}

The authors are thankful to The Principal, Yuvaraja's College, UOM, Mysuru, and The Management and The Principal, VVCE, Mysuru, for providing necessary facilities and constant encouragement.

\section{Conflicts of Interest}

The authors declare no conflict of interest.

\section{References}

1. Dagdu, K.; Gadhave, M.; Bhujbal, S.; Shrinath, B. Area Under Curve by UV Spectrophotometric Method for Determination Albendazole in Bulk. Journal of Drug Delivery and Therapeutics 2019, 9, 47-50, https://doi.org/10.22270/jddt.v9i6.3667.

2. Horton, J. Albendazole: a review of anthelmintic efficacy and safety in humans. Parasitology 2000, 121 Suppl, S113-132, https://doi.org/10.1017/s0031182000007290.

3. Marciocha, D.; Kalka, J.; Turek-Szytow, J.; Surmacz-Górska, J. A Pretreatment Method for Analysing Albendazole by HPLC in Plant Material. Water, Air, \& Soil Pollution 2013, 224, https://doi.org/10.1007/s11270-013-1646-6.

4. Jia, Y.; Selva, C.; Zhang, Y.; Li, B.; McFawn, L.A.; Broughton, S.; Zhang, X.; Westcott, S.; Wang, P.; Tan, C.; Angessa, T.; Xu, Y.; Whitford, R.; Li, C. Uncovering the evolutionary origin of blue anthocyanins in cereal grains. The Plant Journal 2020, 101, 1057-1074, https://doi.org/10.1111/tpj.14557.

5. Sowjanya, S.; Devadasu, C. Development of RP-HPLC Method for the Simultaneous Quantitation of Levamisole and Albendazole: Application to Assay Validation. Int J Anal Chem 2018, 2018, https://doi.org/10.1155/2018/5746305.

6. Anadol, D.; Ozçelik, U.; Kiper, N.; Göçmen, A. Treatment of hydatid disease. Paediatr Drugs 2001, 3, 123 135, https://doi.org/10.2165/00128072-200103020-00005.

7. Webster, J.P.; Gower, C.M.; Knowles, S.C.L.; Molyneux, D.H.; Fenton, A. One health - an ecological and evolutionary framework for tackling Neglected Zoonotic Diseases. Evolutionary Applications 2016, 9, 313333, https://doi.org/10.1111/eva.12341.

8. Moiseev, R.V.; Morrison, P.W.J.; Steele, F.; Khutoryanskiy, V.V. Penetration Enhancers in Ocular Drug Delivery. Pharmaceutics 2019, 11, https://doi.org/10.3390/pharmaceutics11070321.

9. Kimaro, E.; Tibalinda, P.; Shedafa, R.; Temu, M.; Kaale, E. Formulation development of chewable albendazole tablets with improved dissolution rate. Heliyon 2019, 5, https://doi.org/10.1016/j.heliyon.2019.e02911.

10. Rashed, N.S.; Zayed, S.; Abdelazeem, A.; Fouad, F. Development and validation of a green HPLC method for the analysis of clorsulon, albendazole, triclabendazole and ivermectin using monolithic column: Assessment of the greenness of the proposed method. Microchemical Journal 2020, 157, https://doi.org/10.1016/j.microc.2020.105069.

11. Morris, D.L.; Jourdan, J.L.; Pourgholami, M.H. Pilot study of albendazole in patients with advanced malignancy. Effect on serum tumor markers/high incidence of neutropenia. Oncology 2001, 61, 42-46, https://doi.org/10.1159/000055351.

12. Madrim, M.F.; Anaanthan, B.P.; Mohamed, N.E.; Azmawati, M.; Norfazilah, A.; Ghazi, H.; Jeffree, M.; Syed Abdul Rahim, S.S.; Hassan, M.R. Efficacy of Albendazole Against Soil-transmitted Helminthiasis 
among Children in Asia: Systematic Review. Open Access Macedonian Journal of Medical Sciences 2020, 8, 70-77, https://doi.org/10.3889/oamjms.2020.4305.

13. Theodore, E.N.; Bartelt, L/ Giardia lamblia. Mandell, Douglas, and Bennett's Principles and Practice of Infectious Diseases. Philadelphia, PA: Elsevier 2020.

14. Howell, A.K.; Williams, D.J.L. The Epidemiology and Control of Liver Flukes in Cattle and Sheep. Veterinary Clinics of North America: Food Animal Practice 2020, 36, 109-123, https://doi.org/10.1016/j.cvfa.2019.12.002.

15. Bonato, P.S.; Oliveira, A.R.M.d.; Santana, F.J.M.d.; Fernandes, B.J.D.; Lanchote, V.L.; Gonzalez, A.E.; Garcia, H.H.; Takayanagui, O.M. Simultaneous determination of albendazole metabolites, praziquantel and its metabolite in plasma by high-performance liquid chromatography-electrospray mass spectrometry. Journal of Pharmaceutical and Biomedical Analysis 2007, 44, 558-563, https://doi.org/10.1016/j.jpba.2006.11.020.

16. Basavaiah, K.; Prameela, H.C. Two simple methods for the estimation of albendazole and its dosage forms using chloramine-T. Farmaco (Societa chimica italiana : 1989) 2003, 58, 527-534, https://doi.org/10.1016/s0014-827x(03)00067-3.

17. Waldia, A.; Gupta, S.; Issarani, R.; Nagori, B. Validated liquid chromatographic method for simultaneous estimation of albendazole and ivermectin in tablet dosage form. Indian Journal of Chemical Technology 2008, 15, 617-620.

18. Sandhya Bhimrao, L.; Deokate, U.A. Development and validated UV spectrophotometric method for estimation of albendazole in tablet dosage form. World J. Pharm. Res. 2014, 4, 1461-1467.

19. Varghese, S.J. Simultaneous densitometric determination of Ivermectin and Albendazole by highperformance thin-layer chromatography. JPC - Journal of Planar Chromatography - Modern TLC 2011, 24, 344-347, https://doi.org/10.1556/JPC.24.2011.4.13.

20. de Oliveira, M.F.; Stradiotto, N.R. Voltammetric Assay Of Albendazole In Pharmaceutical Dosage Forms. Analytical Letters 2001, 34, 377-387, https://doi.org/10.1081/AL-100102580.

21. Gerssen; Arjen; Patrick, P.J. M.; Mairead, A.; Jacob, B. Liquid chromatography-tandem mass spectrometry method for the detection of marine lipophilic toxins under alkaline conditions. J. Chromatogr. 2009, 9, 14211430. https://doi.org/10.1016/j.chroma.2008.12.099.

22. Swamy, N.; Basavaiah, K. Simple and rapid spectrophotometric assay of albendazole in pharmaceuticals using iodine and picric acid as CT complexing agents \% J Brazilian Journal of Pharmaceutical Sciences. 2014, 50, 839-850, https://doi.org/10.1590/S1984-82502014000400019.

23. Šlampová, A.; Malá, Z.; Gebauer, P. Recent progress of sample stacking in capillary electrophoresis (20162018). Electrophoresis 2019, 40, 40-54, https://doi.org/10.1002/elps.201800261.

24. Valois, M.; Takayanagui, O.; Bonato, P.; Lanchote, V.; Carvalho, D. Determination of Albendazole Metabolites in Plasma by HPLC. Journal of analytical toxicology 1994, 18, 86-90, https://doi.org/10.1093/jat/18.2.86.

25. Lundberg, S.S. Mitigation of production losses associated with ruminant gastrointestinal nematode infections by induction of mucosal tolerance: A thesis submitted in partial fulfilment of the requirements for the Degree of Doctor of Philosophy at Lincoln University. PhD diss., Lincoln University, 2019.

26. Kumar, K.; Umesha, K.B.; Rai, K. Iodometric determination of ascorbic acid in bulk and vitamin-C tablets using chloramine-T. Oxidation Communications 2002, 25, 566-570.

27. Rai, K.M.L.; Umesha, K.B.; Yathirajan, H.S. Determination of molecular weight of neutral amino acids with chloramine-T. J. Indian Chem. Soc, 1999, 3, 170-171.

28. Umesha, K.; Rai, K.; Kumar, K.; Prasad, K.; Shashikanth, S. A New Approach to the Determination of the Number ofOxo Groups in Carbonyl Compounds Using the Chloramine-T Oxidative Method. Chemia analityczna 2001, 46, 269-274.

29. Umesha, K.B.; Rai, K.; Kumar, K.; Khanum, S. A new approach for the determination of percentage of the enol form in the $\square$-ketocarbonyl compounds using chloramine-T oxidative method, Oxid. Commun., 2004, 27, 831-835. Oxidation Communications 2004, 27,

30. Verma; Krishna, K.; Anil, K. G.; Determination of vitamin C with chloramine-T. Anal. Chem., 1980, 14, 2336-2338, https://doi.org/10.1021/ac50064a601.

31. Shubakara, K.; Umesha, K.B.; Srikantamurthy, N. Iodometric determination of gabapentin in tablets using chloramine-T oxidant. Oxidation communications 2013, 36, 410-414.

32. Ruff, F.; Kucsman, Á. Studies On The Stereomechanism Of The Reaction Of Sulphides With ChloramineT. Phosphorus and Sulfur and the Related Elements 1979, 6, 261-261, https://doi.org/10.1080/03086647908080404. 